\title{
Transgenic Mouse Models_-A Seminal Breakthrough in Oncogene Research
}

\author{
Harvey W. Smith and William J. Muller ${ }^{1}$ \\ Department of Biochemistry and Goodman Cancer Research Center, McGill University, Montreal, Quebec \\ H3A 1A3, Canada
}

Transgenic mouse models are an integral part of modern cancer research, providing a versatile and powerful means of studying tumor initiation and progression, metastasis, and therapy. The present repertoire of these models is very diverse, with a wide range of strategies used to induce tumorigenesis by expressing dominant-acting oncogenes or disrupting the function of tumor-suppressor genes, often in a highly tissue-specific manner. Much of the current technology used in the creation and characterization of transgenic mouse models of cancer will be discussed in depth elsewhere. However, to gain a complete appreciation and understanding of these complex models, it is important to review the history of the field. Transgenic mouse models of cancer evolved as a new and, compared with the early cell-culture-based techniques, more physiologically relevant approach for studying the properties and transforming capacities of oncogenes. Here, we will describe early transgenic mouse models of cancer based on tissue-specific expression of oncogenes and discuss their impact on the development of this still rapidly growing field.

During the 1970s and 1980s, major advances in the fields of molecular biology and molecular genetics resulted in new technologies that facilitated transgenesis in the laboratory mouse. This was also an era when the molecular events underlying tumorigenesis began to be characterized, with much effort focused on identifying oncogenes and understanding their functions (Duesberg and Vogt 1970; Martin 1970; Stehelin et al. 1976). At this time, in vivo studies of tumorigenesis using the mouse as a model organism relied primarily on xenograft models and environmental carcinogens such as chemicals, tumor viruses, or radiation. However, the xenograft approach, although useful for studying the capacity of oncogene-transformed cells to grow in an in vivo environment, suffers from many drawbacks. For example, owing to the nature of many xenograft models, tumors do not form within their proper tissue and immune microenvironment. Furthermore, xenografted tumors do not reproduce the processes of neoplastic progression from an initially normal cell through multiple premalignant stages to yield a tumor (Becher and Holland 2006; Frese and Tuveson 2007). Environmental carcinogenesis models have proven to be very useful for identifying tumor-initiating and tumorpromoting events and for studying the role of environmental factors in the development of cancer (Hirst and Balmain 2004). However, these models are not sufficiently experimentally tractable to allow the study of defined oncogenes in specific cell types.

\footnotetext{
${ }^{1}$ Correspondence: william.muller@mcgill.ca 
Because the advent of transgenic mouse models occurred in the context of rapidly intensifying interest and expanding knowledge of both viral and cellular oncogenes, it is not surprising that a number of groups began to explore the possibility of combining these two areas of research. Transgenic mice presented an opportunity to test whether proposed oncogenes could cause cancer when expressed by normal cells in their proper context within a mammalian model organism. Some proof of principle for this concept was provided by the 1974 study of Rudolph Jaenisch and Beatrice Mintz, where DNA harboring viral oncogenes (known as T-antigens) from simian virus 40 (SV40), a polyomavirus known to cause oncogenic transformation in cell culture and in some animal models (Sweet and Hilleman 1960; Kirschstein and Gerber 1962; Dulbecco 1964), was microinjected into the blastocoel (fluid-filled central cavity) of mouse embryos (Jaenisch and Mintz 1974). The resulting mice did not develop tumors, but viral DNA was detectable in many of their tissues-their significance is that they are considered to be the first transgenic mice. However, these mice did not transmit the SV40 DNA to their offspring. Following these experiments with SV40, Jaenisch was able to demonstrate successful germline transmission of Moloney murine leukemia virus DNA upon viral infection of mouse embryos. Inheritance of the viral genome led to leukemogenesis in successive generations of transgenic mice, which was associated with the production of functional virus and detectable viremia in these mice (Jaenisch 1976).

While these early studies did not lead to the establishment of widely used transgenic mouse models of cancer, they proved that it was possible to introduce exogenous oncogenes into the mouse germline and inspired the development of a new generation of models. Although a detailed technical discussion is beyond the scope of this article, it is important to note that the development of technology for pronuclear microinjection of DNA into mouse zygotes by several laboratories in the early 1980s was an essential breakthrough for this nascent field of research (Gordon et al. 1980; Brinster et al. 1981; Gordon and Ruddle 1981; Wagner et al. 1981). This technique allows virtually any DNA sequence to be introduced into the mouse germline, with a relatively high success rate. Typically, multiple copies of the microinjected DNA integrate into the mouse genome as concatamers at a single random site before embryonic cleavage (Brinster et al. 1981; Gordon and Ruddle 1985). Although multiple integration sites are sometimes observed, their frequency is reduced compared with that of earlier methods. Although it still presented a substantial technical challenge, pronuclear microinjection greatly simplified the establishment of new lines of transgenic mice (see Fig. 1 for a time line). More recently, these microinjection techniques have been applied to very large DNA constructs, including bacterial artificial chromosomes (BACs) (Yang et al. 1997; Sparwasser et al. 2004) and yeast artificial chromosomes (YACs) (Schedl et al. 1993), which can contain several hundred kilobases of DNA. A major advantage of this approach is the potential for the inclusion of most or all endogenous regulatory sequences within the transgenic construct. This is thought to largely preclude hostgenome positional effects that can contribute to lack of tissue-specific gene expression, which are described further below.

\section{EARLY TRANSGENIC MOUSE MODELS OF CANCER: BRAIN TUMORS INDUCED} BY SV40 LARGE T-ANTIGEN

Among the pioneers of pronuclear microinjection were Ralph Brinster and Richard Palmiter, who used this technique to generate transgenic mice expressing herpes simplex virus thymidine kinase (HSV-TK) (Brinster et al. 1981) or human growth hormone (SOMA/somatotropin, encoded by the GH1 gene) (Palmiter et al. 1982), under the transcriptional control of the metallothionein-1 (Mt-1) promoter. To increase the expression of these transgenes, Brinster and Palmiter created new constructs incorporating the SV40 early region, which contains a powerful transcriptional enhancer. These composite transgenes were known as SV-MK (with the HSV-TK gene) and SV-MGH (with the GH gene). However, the added viral DNA also encoded the SV40 T-antigens (Black et al. 1963), which at that time were thought to be unable to cause transformation in mice (Brinster et al. 1984; Hanahan et al. 2007), although they were known to transform cultured mouse cells (Tegtmeyer et al. 


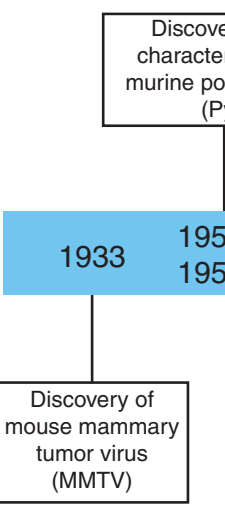

Discovery/initial

characterization of (PyV)

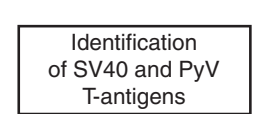

\section{Microinjection} of SV40 DNA into embryos yields

the first transgenic mice
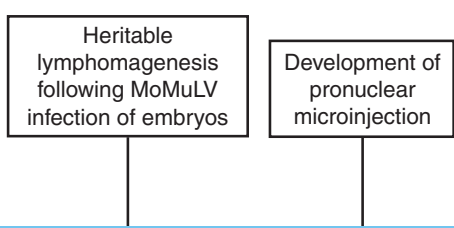
pronuclear
microinjection

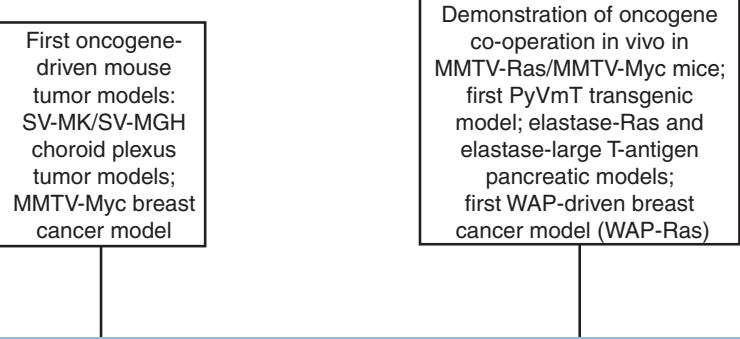

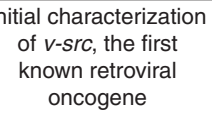
of $v$-src, the first known retroviral oncogene

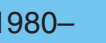

$1981 \quad 1983$
Identification and study of endogenous tissuespecific promoters including elastase, myosin

light chain, $\beta$-globin, immunoglobulin heavy and light chains
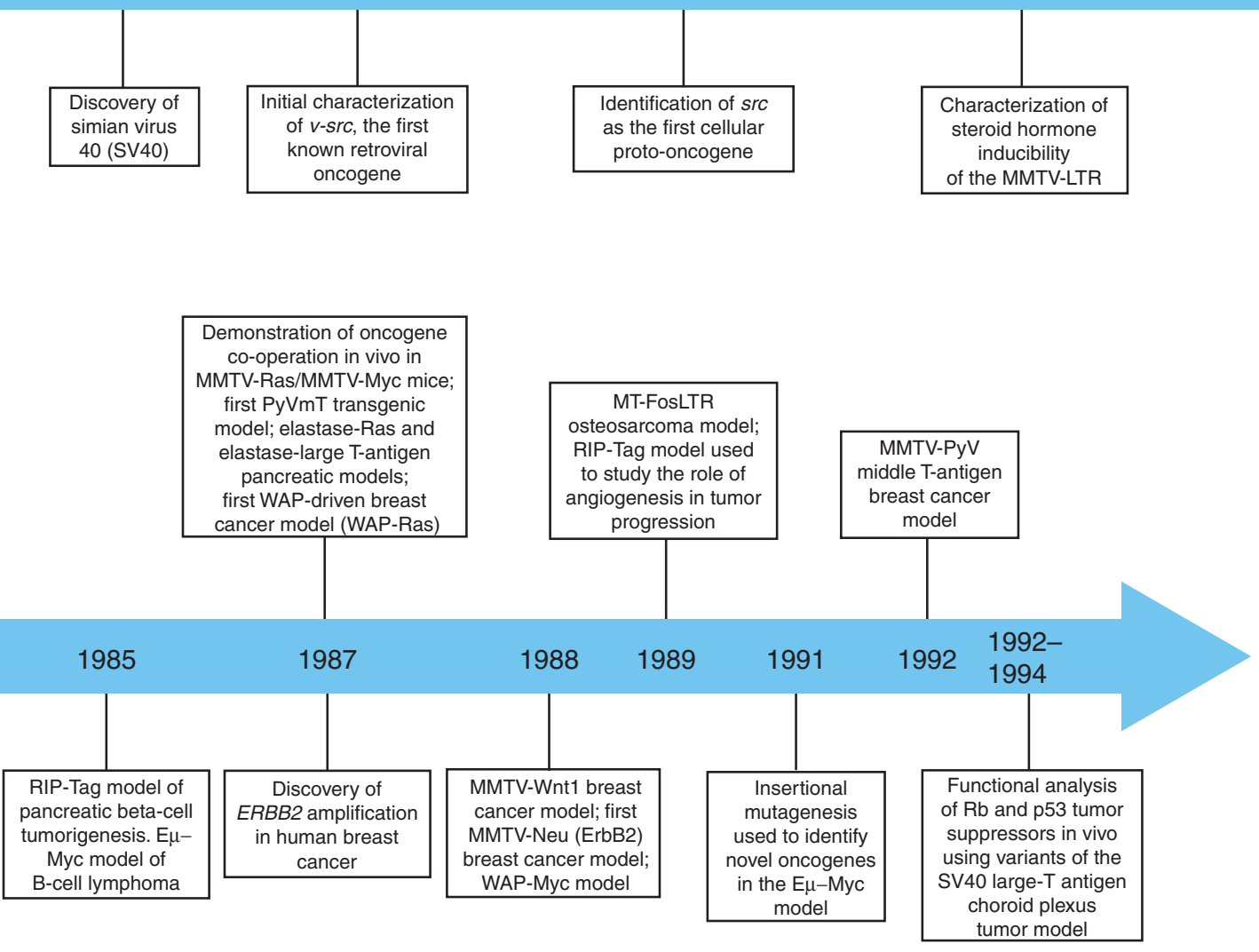

FIGURE 1. A time line illustrating the early decades of development of transgenic mouse models of cancer. For clarity, we have focused on a selection of transgenic models that had a large impact on this area of research. As the development of transgenic mouse models was closely linked with the discovery and characterization of oncogenes, we have included some key events in the study of tumor virology and oncogenes that were vital for the establishment and growth of the field. We also indicate some of the notable early discoveries facilitated by the use of oncogene-driven transgenic models. Original papers describing the work indicated here are referred to in the main text.

1975; Sleigh et al. 1978). Strikingly, the resulting transgenic mouse strains developed tumors originating from the choroid plexus epithelium of the ventricles of the brain, which showed complete penetrance (Brinster et al. 1984). Further analysis using transgenic mice expressing versions of the constructs lacking particular regions revealed that these tumors were dependent on the function of the SV40 enhancer and the large T-antigen, requiring neither the HSV-TK or GH transgenes nor the small T-antigen (Palmiter et al. 1985).

Through their demonstration that SV40 T-antigens could indeed be oncogenic in mice, Brinster and Palmiter established one of the first transgenic mouse models of cancer. Although this model was not intentionally designed to limit oncogene expression to a particular cell or tissue type, the brain tumor phenotype of mice expressing $S V-M K$ and $S V-M G H$ transgenes reflects a degree of tissue specificity. However, it is clear that the spectrum of tumors that can arise in models such as these 
is extremely difficult to predict. Targeted expression of oncogenes in specific cell or tissue types is a more accurate way of modeling many human cancers, which occur through mutation or overexpression of oncogenes in a very specific cellular context rather than throughout the organism. Achieving rationally targeted expression of oncogenes in defined cell types was an early goal for the field of transgenic mouse models of cancer. Notably, the same strategies used to express oncogenes in specific murine tissues have also been used to ablate the function of tumor-suppressor genes in a tissuespecific fashion. For example, the use of tissue-specific promoters has been combined with conditional gene targeting technologies, such as the Cre-LoxP system, for this purpose. These types of models are described in detail elsewhere.

\section{TRANSGENIC MOUSE MODELS OF BREAST CANCER: THE MMTV PARADIGM}

One strategy for achieving tissue-specific control of oncogene expression involved exploiting the natural tropism of tumor-inducing viruses known to cause specific types of cancer reproducibly in mice. An important example of such a virus is the mouse mammary tumor virus (MMTV), a retrovirus that had been identified as the "milk agent," passed from mother to pup, responsible for causing mammary tumors in susceptible strains of inbred mice (Jackson and Little 1933; Cardiff and Kenney 2007). Decades of study of MMTV had led to the discovery that the virus harbors a regulatory DNA sequence, the long terminal repeat (LTR), that promotes steroid-hormone-inducible transcription (Ringold et al. 1975; Yamamoto et al. 1981, 1983). Insertion of the MMTV provirus into the murine genome adjacent to a proto-oncogene confers overexpression in mammary epithelial cells responding to hormonal stimulation during pregnancy and lactation, leading to mammary tumors in MMTV-infected female mice (Nusse and Varmus 1982; Nusse et al. 1984; Sonnenberg et al. 1987). Using the integrated provirus as a "tag," the characterization of MMTV insertion sites led to the discovery of novel oncogenes, most notably at the major integration sites Int1 (corresponding to the Wnt1 gene) (Nusse et al. 1984), Int2 (corresponding to the fibroblast growth factor Fgf3/Int2 gene) (Dickson et al. 1984), and Int3 (corresponding to the Notch gene) (Jhappan et al. 1992). However, the tissue specificity of MMTV-driven tumorigenesis, the hormone-inducible nature of oncogene expression in these tumors, and the characterization of the transcriptional enhancer responsible for this also presented a great opportunity for the design of novel transgenic mouse models of cancer.

Recognizing the potential utility of the MMTV-LTR for the study of breast cancer, Phil Leder sought to exploit this viral enhancer to create the first transgenic mouse models of this disease. It had already been shown by this time that hormone-induced oncogene expression could occur in cultured cells after the introduction of an MMTV-H-Ras vector (Huang et al. 1981). Leder and Timothy Stewart, a postdoctoral fellow in his laboratory, subsequently used pronuclear microinjection to generate transgenic mice expressing the oncogene $M y c$ under the control of the MMTV-LTR. Careful analysis of these MMTV-Myc mice demonstrated the development of Myc-driven mammary tumors in female mice from two of the founder lines following the stimulation of expression from the MMTV-LTR by multiple rounds of pregnancy and lactation (Stewart et al. 1984). This was another defining moment in the history of transgenic mouse models of cancer as well as in breast cancer research. A subsequent study from the Leder laboratory described an MMTV-H-Ras model, which helped one to establish the in vivo transforming capacity of activated Ras in mammalian tissues (Sinn et al. 1987). In this study, the MMTV-Myc and MMTV-Ras mice were crossed, with a resulting acceleration in tumorigenesis that demonstrated oncogene cooperation for the first time in vivo (Sinn et al. 1987). In a remarkable convergence of MMTV virology and molecular oncology with the new transgenic technology, the laboratory of Harold Varmus published the MMTV-Int1 (now known as MMTV-Wnt1) model in 1988, validating this proviral insertion site as a genuine proto-oncogene that could induce mammary tumors (Tsukamoto et al. 1988). At the same time, the MMTV-LTR was used to demonstrate the capability of the receptor tyrosine-protein kinase ErbB2, an oncogene amplified and overexpressed in $\sim 20 \%$ of human breast cancers (Slamon et al. 1987), to transform the mouse mammary epithelium (Muller et al. 1988). Transgenic mouse models of ErbB2-driven breast cancer, 
which have increased over the years in their complexity and their ability to accurately model the human disease, have proved to be invaluable for mechanistic studies of mammary gland transformation by this important oncogene and therapeutic target (Ursini-Siegel et al. 2007).

Many of the early MMTV-based mouse models of breast cancer are still in use today, and the MMTV-LTR remains an important tool for the in vivo validation of candidate breast cancer oncogenes. Additionally, subsequent work from several laboratories has resulted in the characterization of endogenous murine mammary-epithelial-specific promoters that have been used to create transgenic mice. One such promoter is that of the whey acidic protein (Wap) gene (Campbell et al. 1984). Interestingly, expression of oncogenic $\mathrm{H}$-Ras from this hormone-dependent promoter results in a mild phenotype, with alveolar hyperplasias that, in contrast to the MMTV-driven Ras model (Sinn et al. 1987), infrequently progress to adenocarcinoma (Andres et al. 1987). Although Wap-promoted Myc expression leads to nearly complete penetrance of mammary tumors following multiple rounds of pregnancy and lactation, these tumors are morphologically and phenotypically very distinct from MMTV-Myc tumors (Schoenenberger et al. 1988). The distinct phenotypes observed in these models may be due to differences in the subpopulations of mammary epithelial cells that express MMTVLTR- and WAP-driven transgenes, resulting in different cells of origin for these tumors (Robinson et al. 1995; Gallahan et al. 1996; Wagner et al. 1997).

\section{TISSUE SPECIFICITY OF ONCOGENE EXPRESSION AND TRANSFORMATION USING VIRAL PROMOTER/ENHANCER-DRIVEN ONCOGENES}

Although it is a useful tool for engineering transgenic mice with mammary epithelial-targeted oncogene expression, there is considerable evidence that transcription driven by the MMTV-LTR is not absolutely tissue-specific (Stewart et al. 1984; Choi et al. 1987; Sinn et al. 1987; Wagner et al. 2001). It is also important to note that the random nature of transgene integration following pronuclear injection is a very important factor in determining the tissue specificity of gene expression. Multiple transgenic lines derived using the same DNA construct often exhibit varying degrees of tissue-specific expression, indicating a strong positional effect of the transgene integration site (Stewart et al. 1984; Sinn et al. 1987; Wagner et al. 1997). For these reasons, many transgenic lines containing MMTV-LTR-driven oncogenes exhibit transgene expression and tumorigenesis in several tissues. For example, in addition to mammary tumors, one of the MMTV-Myc founder lines developed Myc-driven testicular and hematopoietic tumors (Leder et al. 1986), whereas MMTVRas mice developed salivary gland, Harderian gland (a type of accessory lacrimal gland not found in humans), and lymphoid tumors (Sinn et al. 1987). Although this issue must be considered when designing and characterizing transgenic mouse models, it is also highly illustrative of the limitations on the spectrum of tissues that can be transformed by a given oncogene. In many studies using viral promoter or enhancer elements, the oncogenes are expressed to similar levels in multiple tissues, whereas the tumors typically develop in only a subset of these tissues. The SV-MK/SV-MGH models described above express SV40 large T-antigen in the thymus and kidney in addition to the choroid plexus. However, tumorigenesis in these tissues is exceedingly rare (Brinster et al. 1984). In another example, a hybrid construct containing a sequence from the FBJ murine sarcoma virus was used in the laboratory of Erwin Wagner to target expression of the Fos oncogene to mesenchymal cells of transgenic mice. Although this transgene was widely expressed, the mice developed only osteosarcomas (Ruther et al. 1989). In the laboratory of Douglas Hanahan, transgenic mice expressing the middle T-antigen of murine polyomavirus (PyVmT) (Gross 1953; Habel 1965) under the control of polyomavirus early-region regulatory sequences were found to develop exclusively endothelial cell tumors (hemangiomas), suggesting that these cells are particularly sensitive to transformation by PyVmT (Bautch et al. 1987). However, later studies using more-tissue-specific strategies have revealed that $\mathrm{PyVmT}$ is indeed capable of inducing tumorigenesis in several other organs (Tehranian et al. 1996; Cecena et al. 2006). The most notable example used the MMTV-LTR to express PyVmT in the mammary epithelium, leading to rapid development of highly metastatic mammary tumors (Guy 
H.W. Smith and W.J. Muller

et al. 1992). This has become a very important model for the study of mammary tumor progression and metastasis (Maglione et al. 2001; Fluck and Schaffhausen 2009).

\section{MODELING BURKITT'S LYMPHOMA IN TRANSGENIC MICE: THE E $\mu-M y c$ MODEL}

While the first MMTV-driven transgenic mouse models of cancer were being developed, other groups used transgenic mice to study the tissue specificity of transcriptional regulatory elements. These experiments initially were focused on elucidating transcriptional mechanisms controlling normal mammalian differentiation and development. Introducing transgenes under the control of a purported tissue-specific promoter and assaying gene expression in multiple tissues allowed thorough and rigorous testing of the tissue specificity of gene expression. Numerous tissue-specific promoters were successfully identified and studied using this approach in the early 1980s (Palmiter and Brinster 1985). At the same time, knowledge of the genetic events leading to the overexpression of oncogenes in certain tumors was growing rapidly. Many of these studies converged on recurring rearrangements of the $M Y C$ oncogene in human B-cell lymphomas and its orthologs in animal models of this disease. For example, in avian B-cell lymphomas induced by the avian leukosis virus, proviral insertion adjacent to the c-myc proto-oncogene was found to cause Myc overexpression owing to the activity of the viral enhancer (Hayward et al. 1981). Strikingly, studies of human Burkitt's lymphoma identified the crucial oncogenic event in this disease as a chromosomal translocation placing $M Y C$ within or adjacent to one of the immunoglobulin heavy chain genes (Dalla-Favera et al. 1982; Taub et al. 1982). Alterations in regulatory sequences within the translocated $M Y C$ gene and the activity of specific transcriptional enhancers within the immunoglobulin locus then cause Myc overexpression and tumorigenesis within the B-cell lineage (Hayday et al. 1984; Wiman et al. 1984; Polack et al. 1993; Madisen and Groudine 1994). Murine plasmacytomas were also found to harbor similar chromosomal rearrangements, including a translocation that placed c-myc in close proximity to the immunoglobulin heavy chain enhancer known as $\mathrm{E} \mu$ (Taub et al. 1982; Adams et al. 1983; Corcoran et al. 1985). At around the same time, studies using transgenic mice demonstrated that transgene expression could be targeted to lymphoid cells by using constructs containing immunoglobulin enhancers (Grosschedl et al. 1984; Storb et al. 1984).

Together, these discoveries led to the development of a transgenic mouse model of B-cell lymphoma. Once the nature of the Burkitt's lymphoma chromosomal rearrangements was known, Palmiter and Brinster initiated a collaboration with Jerry Adams and Suzanne Cory to model this disease by making transgenic mice expressing a construct that recapitulated the $\mathrm{E} \mu-\mathrm{Myc}$ fusion (Adams et al. 1985). These mice developed B- and pre-B-cell lymphomas at a very high frequency owing to the stimulation of c-Myc expression in these cells (Adams et al. 1985). Many aspects of the lymphomas that developed in these transgenic mice were found to model various features of the human disease, including progression through a distinct premalignant phase (Langdon et al. 1986). The impact of the E $\mu-\mathrm{Myc}$ model on cancer research has been considerable. Along with SV40 Tantigen-based models, these mice were important in early studies on the roles of tumor-suppressor pathways during transformation in vivo (Chen et al. 1992; Eischen et al. 1999; Schmitt et al. 1999). By using insertional mutagenesis screens based on provirus tagging approaches, several genes with relevance to human cancer and normal developmental processes have been discovered by means of the $\mathrm{E} \mu-\mathrm{Myc}$ model (Haupt et al. 1991; van Lohuizen et al. 1991). More recently, E $\mu-\mathrm{Myc}$ mice have been combined with in vivo RNA interference technology as a means of conducting forward-genetic screens in transgenic mouse models, culminating in a large-scale screening experiment that identified novel therapeutic targets (Zuber et al. 2011).

TISSUE-SPECIFIC ONCOGENE EXPRESSION IN THE MURINE PANCREAS: RIP-TAG AND ELASTASE-PROMOTER-DRIVEN MODELS

As studies of tissue-specific gene expression in the mouse continued to progress, several groups focused on promoters thought to confer highly specific expression within cells of the pancreas. 
In vitro experiments using DNA constructs with rat and human insulin gene promoters demonstrated high levels of expression in cells derived from endocrine pancreatic tumors (Walker et al. 1983). A seminal study in 1985 by Douglas Hanahan aimed to test the in vivo tissue specificity of the rat insulinII promoter while also examining the effect of expressing an oncogene in the targeted cells (Hanahan 1985). Transgenic mice were created using constructs containing SV40 T-antigens under the control of the rat insulin-II promoter in forward and reverse configurations, known as RIP-Tag and RIR-Tag, respectively. These mice all died prematurely, with clear abnormalities of the pancreas but no other obvious pathology (Hanahan 1985). Further pathological analysis confirmed the presence of hyperplasia and solid tumors within the pancreatic islets of Langerhans, which was associated with the expression of SV40 large T-antigen specifically in the pancreatic $\beta$-cells of these mice (Hanahan 1985).

The main transgenic mouse line propagated from this initial study, known as RIP1-Tag2, has become well established as a model of pancreatic neuroendocrine tumors originating from $\beta$-cells. Among the many discoveries made using this model, one of the most important was the role of the angiogenic switch in tumor progression. It was obvious from the original study that RIP1-Tag2 tumors exhibited a multi-stage progression, as SV40 large T-antigen expression could be seen in histologically normal $\beta$-cells, hyperplastic islets and fully developed carcinomas (Hanahan 1985). Other important initial observations were that only a small fraction of the hyperproliferative islets seen in RIP1-Tag2 mice were capable of forming carcinomas and that these late-stage solid tumors were highly vascularized. Through the work of Hanahan and Judah Folkman, tumor progression was correlated with the ability to recruit new vasculature, and the pro-angiogenic nature of a minority of RIP1-Tag2 pancreatic lesions was further confirmed in a series of in vitro co-culture assays with endothelial cells (Folkman et al. 1989). The idea that the activation of angiogenesis was an essential, rate-limiting step in neoplastic progression has been validated in a number of other models (Bergers and Benjamin 2003). These findings contributed greatly to a large expansion in angiogenesis research, with an ongoing interest in antiangiogenic strategies for cancer therapy (Ferrara and Kerbel 2005).

While Hanahan was developing his model of pancreatic islet tumorigenesis, Palmiter and Brinster focused on the exocrine pancreas, a tissue known to express relatively few mRNAs, many of which were thought to be highly cell-type-specific (MacDonald et al. 1986). Using a series of transgenic mice with rat elastase or human growth hormone genes under the control of the rat elastase-I promoter, they demonstrated very specific transgene expression in mouse pancreatic acinar cells, with levels of mRNA expression at least 10,000-fold higher than that of other tissues examined (Swift et al. 1984; Ornitz et al. 1985; MacDonald et al. 1986). This provided proof of principle for the establishment of transgenic mice expressing oncogenes under the control of this promoter. Such models expressing the SV40 large $\mathrm{T}$-antigen or an oncogenic mutant of $\mathrm{H}$-Ras developed highly penetrant pancreatic tumors, whereas expression of Myc had no discernible effect (Ornitz et al. 1987; Quaife et al. 1987). The resulting tumors were acinar in nature, reflecting the highly cell-specific activity of the elastase-I promoter. By helping to establish that Ras oncogenes could transform cells of the exocrine pancreas in vivo, the elastase-Ras model foreshadowed later developments in pancreatic cancer modeling. More recent studies have used tissue-specific expression of clinically relevant mutants of the Kras oncogene to create several elegant models of pancreatic ductal and acinar adenocarcinomas and their precursor lesions, exploiting a variety of promoters specific for various cellular compartments of the exocrine pancreas, including Pdx1, p48, and Mist-1 (Aguirre et al. 2003; Hingorani et al. 2003, 2005; Tuveson et al. 2006).

\section{CONCLUSIONS AND PERSPECTIVES}

Here, we have attempted to present an overview of early transgenic mouse models of cancer based on tissue-specific expression of oncogenes. The original methodology for the generation of transgenic mice remains valid and still widely used. However, the strategies used to design transgenic mouse models have evolved greatly since the generation of these first models. Modern transgenic constructs have become increasingly sophisticated to reflect expanding knowledge of gene regulation and the 
processes underlying tumorigenesis. For example, although it has not yet been extensively applied to the study of oncogenes in vivo, BAC transgenesis has been used recently to overexpress the tumor suppressor PTEN (phosphatase and tensin homolog) in mice (Garcia-Cao et al. 2012). The early transgenic mouse models of cancer described here are the foundation upon which this field was built and have proved to be instrumental in the in vivo validation of candidate oncogenes and the elucidation of their mechanisms of action. While some of the transgenic models discussed here are now largely historical, many of them continue to serve as important tools for studies of tumor initiation and progression as well as for the evaluation of novel therapeutics. This is illustrated by recent innovative studies that have applied new technologies to well-established models such as E $\mu-\mathrm{Myc}$ and MMTV-PyV mT, yielding novel and significant results (DeNardo et al. 2009; Zuber et al. 2011). The emergence of new models based closely on some of the original ones discussed above also illustrates their influence and the adaptability of the approach. Transgenic models of ErbB2-driven breast cancer are a good example of this, having gone through numerous iterations from the original model in 1988 to the present (Ursini-Siegel et al. 2007). With many important questions about oncogene function remaining unanswered, classical oncogene-driven transgenic mouse models of cancer will remain a valuable resource and a sound basis for the development of novel, updated models that are an even more relevant representation of human cancer.

\section{REFERENCES}

Adams JM, Gerondakis S, Webb E, Corcoran LM, Cory S. 1983. Cellular myc oncogene is altered by chromosome translocation to an immunoglobulin locus in murine plasmacytomas and is rearranged similarly in human Burkitt lymphomas. Proc Natl Acad Sci 80: 1982-1986.

Adams JM, Harris AW, Pinkert CA, Corcoran LM, Alexander WS, Cory S, Palmiter RD, Brinster RL. 1985. The c-myc oncogene driven by immunoglobulin enhancers induces lymphoid malignancy in transgenic mice. Nature 318: 533-538.

Aguirre AJ, Bardeesy N, Sinha M, Lopez L, Tuveson DA, Horner J, Redston MS, DePinho RA. 2003. Activated Kras and Ink4a/Arf deficiency cooperate to produce metastatic pancreatic ductal adenocarcinoma. Genes Dev 17: 3112-3126.

Andres AC, Schonenberger CA, Groner B, Hennighausen L, LeMeur M, Gerlinger P. 1987. Ha-ras oncogene expression directed by a milk protein gene promoter: Tissue specificity, hormonal regulation, and tumor induction in transgenic mice. Proc Natl Acad Sci 84: 1299-1303.

Bautch VL, Toda S, Hassell JA, Hanahan D. 1987. Endothelial cell tumors develop in transgenic mice carrying polyoma virus middle $\mathrm{T}$ oncogene. Cell 51: 529-537.

Becher OJ, Holland EC. 2006. Genetically engineered models have advantages over xenografts for preclinical studies. Cancer Res 66: 3355-3359.

Bergers G, Benjamin LE. 2003. Tumorigenesis and the angiogenic switch. Nat Rev Cancer 3: 401-410.

Black PH, Rowe WP, Turner HC, Huebner RJ. 1963. A specific complementfixing antigen present in Sv40 tumor and transformed cells. Proc Natl Acad Sci 50: 1148-1156.

Brinster RL, Chen HY, Trumbauer M, Senear AW, Warren R, Palmiter RD. 1981. Somatic expression of herpes thymidine kinase in mice following injection of a fusion gene into eggs. Cell 27: 223-231.

Brinster RL, Chen HY, Messing A, van Dyke T, Levine AJ, Palmiter RD. 1984. Transgenic mice harboring SV40 T-antigen genes develop characteristic brain tumors. Cell 37: 367-379.

Campbell SM, Rosen JM, Hennighausen LG, Strech-Jurk U, Sippel AE. 1984. Comparison of the whey acidic protein genes of the rat and mouse. Nucleic Acids Res 12: 8685-8697.

Cardiff RD, Kenney N. 2007. Mouse mammary tumor biology: A short history. Adv Cancer Res 98: 53-116.

Cecena G, Wen F, Cardiff RD, Oshima RG. 2006. Differential sensitivity of mouse epithelial tissues to the polyomavirus middle T oncogene. Am J Pathol 168: 310-320.

Chen J, Tobin GJ, Pipas JM, Van Dyke T. 1992. T-antigen mutant activities in vivo: Roles of $\mathrm{p} 53$ and $\mathrm{pRB}$ binding in tumorigenesis of the choroid plexus. Oncogene 7: 1167-1175.
Choi YW, Henrard D, Lee I, Ross SR. 1987. The mouse mammary tumor virus long terminal repeat directs expression in epithelial and lymphoid cells of different tissues in transgenic mice. J Virol 61: 30133019.

Corcoran LM, Cory S, Adams JM. 1985. Transposition of the immunoglobulin heavy chain enhancer to the myc oncogene in a murine plasmacytoma. Cell 40: 71-79.

Dalla-Favera R, Bregni M, Erikson J, Patterson D, Gallo RC, Croce CM. 1982. Human c-myc onc gene is located on the region of chromosome 8 that is translocated in Burkitt lymphoma cells. Proc Natl Acad Sci 79: 7824-7827.

DeNardo DG, Barreto JB, Andreu P, Vasquez L, Tawfik D, Kolhatkar N, Coussens LM. 2009. $\mathrm{CD}^{+}{ }^{+} \mathrm{T}$ cells regulate pulmonary metastasis of mammary carcinomas by enhancing protumor properties of macrophages. Cancer Cell 16: 91-102.

Dickson C, Smith R, Brookes S, Peters G. 1984. Tumorigenesis by mouse mammary tumor virus: Proviral activation of a cellular gene in the common integration region int-2. Cell 37: 529-536.

Duesberg PH, Vogt PK. 1970. Differences between the ribonucleic acids of transforming and nontransforming avian tumor viruses. Proc Natl Acad Sci 67: 1673-1680.

Dulbecco R. 1964. Transformation of cells in vitro by DNA-containing viruses. J Am Med Assoc 190: 721-726.

Eischen CM, Weber JD, Roussel MF, Sherr CJ, Cleveland JL. 1999. Disruption of the ARF-Mdm2-p53 tumor suppressor pathway in Myc-induced lymphomagenesis. Genes Dev 13: 2658-2669.

Ferrara N, Kerbel RS. 2005. Angiogenesis as a therapeutic target. Nature 438: 967-974.

Fluck MM, Schaffhausen BS. 2009. Lessons in signaling and tumorigenesis from polyomavirus middle T antigen. Microbiol Mol Biol Rev 73: 542563.

Folkman J, Watson K, Ingber D, Hanahan D. 1989. Induction of angiogenesis during the transition from hyperplasia to neoplasia. Nature 339: $58-61$.

Frese KK, Tuveson DA. 2007. Maximizing mouse cancer models. Nat Rev Cancer 7: 645-658.

Gallahan D, Jhappan C, Robinson G, Hennighausen L, Sharp R, Kordon E, Callahan R, Merlino G, Smith GH. 1996. Expression of a truncated Int3 gene in developing secretory mammary epithelium specifically retards lobular differentiation resulting in tumorigenesis. Cancer Res 56: 17751785 .

Garcia-Cao I, Song Min S, Hobbs Robin M, Laurent G, Giorgi C, de Boer Vincent CJ, Anastasiou D, Ito K, Sasaki Atsuo T, Rameh L, et al. 2012. 
Systemic elevation of PTEN induces a tumor-suppressive metabolic state. Cell 149: 49-62.

Gordon JW, Ruddle FH. 1981. Integration and stable germ line transmission of genes injected into mouse pronuclei. Science 214: 1244-1246.

Gordon JW, Ruddle FH. 1985. DNA-mediated genetic transformation of mouse embryos and bone marrow-A review. Gene 33: 121-136.

Gordon JW, Scangos GA, Plotkin DJ, Barbosa JA, Ruddle FH. 1980. Genetic transformation of mouse embryos by microinjection of purified DNA. Proc Natl Acad Sci 77: 7380-7384.

Gross L. 1953. A filterable agent, recovered from Ak leukemic extracts, causing salivary gland carcinomas in $\mathrm{C} 3 \mathrm{H}$ mice. Proc Soc Exp Bio Med 83: 414-421.

Grosschedl R, Weaver D, Baltimore D, Costantini F. 1984. Introduction of a $\mathrm{mu}$ immunoglobulin gene into the mouse germ line: Specific expression in lymphoid cells and synthesis of functional antibody. Cell 38: 647-658.

Guy CT, Cardiff RD, Muller WJ. 1992. Induction of mammary tumors by expression of polyomavirus middle $\mathrm{T}$ oncogene: A transgenic mouse model for metastatic disease. Mol Cell Biol 12: 954-961.

Habel K. 1965. Specific complement-fixing antigens in polyoma tumors and transformed cells. Virology 25: 55-61.

Hanahan D. 1985. Heritable formation of pancreatic $\beta$-cell tumours in transgenic mice expressing recombinant insulin/simian virus 40 oncogenes. Nature 315: 115-122.

Hanahan D, Wagner EF, Palmiter RD. 2007. The origins of oncomice: A history of the first transgenic mice genetically engineered to develop cancer. Genes Dev 21: 2258-2270.

Haupt Y, Alexander WS, Barri G, Klinken SP, Adams JM. 1991. Novel zinc finger gene implicated as $m y c$ collaborator by retrovirally accelerated lymphomagenesis in E $\mu-m y c$ transgenic mice. Cell 65: 753-763.

Hayday AC, Gillies SD, Saito H, Wood C, Wiman K, Hayward WS, Tonegawa S. 1984. Activation of a translocated human c-myc gene by an enhancer in the immunoglobulin heavy-chain locus. Nature 307: 334 340.

Hayward WS, Neel BG, Astrin SM. 1981. Activation of a cellular onc gene by promoter insertion in ALV-induced lymphoid leukosis. Nature 290: 475-480.

Hingorani SR, Petricoin EF, Maitra A, Rajapakse V, King C, Jacobetz MA, Ross S, Conrads TP, Veenstra TD, Hitt BA, et al. 2003. Preinvasive and invasive ductal pancreatic cancer and its early detection in the mouse. Cancer Cell 4: 437-450.

Hingorani SR, Wang L, Multani AS, Combs C, Deramaudt TB, Hruban RH, Rustgi AK, Chang S, Tuveson DA. 2005. Trp53R172H and KrasG12D cooperate to promote chromosomal instability and widely metastatic pancreatic ductal adenocarcinoma in mice. Cancer Cell 7: 469-483.

Hirst GL, Balmain A. 2004. Forty years of cancer modelling in the mouse. Eur J Cancer 40: 1974-1980.

Huang AL, Ostrowski MC, Berard D, Hager GL. 1981. Glucocorticoid regulation of the Ha-MuSV p21 gene conferred by sequences from mouse mammary tumor virus. Cell 27: 245-255.

Jackson RB, Little CC. 1933. The existence of non-chromosomal influence in the incidence of mammary tumors in mice. Science 78: 465-466.

Jaenisch R. 1976. Germ line integration and Mendelian transmission of the exogenous Moloney leukemia virus. Proc Natl Acad Sci 73: 1260-1264.

Jaenisch R, Mintz B. 1974. Simian virus 40 DNA sequences in DNA of healthy adult mice derived from preimplantation blastocysts injected with viral DNA. Proc Natl Acad Sci 71: 1250-1254.

Jhappan C, Gallahan D, Stahle C, Chu E, Smith GH, Merlino G, Callahan R. 1992. Expression of an activated Notch-related int-3 transgene interferes with cell differentiation and induces neoplastic transformation in mammary and salivary glands. Genes Dev 6: 345-355.

Kirschstein RL, Gerber P. 1962. Ependymomas produced after intracerebral inoculation of SV40 into new-born hamsters. Nature 195: 299-300.

Langdon WY, Harris AW, Cory S, Adams JM. 1986. The c-myc oncogene perturbs B lymphocyte development in E $\mu-m y c$ transgenic mice. Cell 47: $11-18$.

Leder A, Pattengale PK, Kuo A, Stewart TA, Leder P. 1986. Consequences of widespread deregulation of the c-myc gene in transgenic mice: Multiple neoplasms and normal development. Cell 45: 485-495.

MacDonald RJ, Hammer RE, Swift GH, Ornitz DM, Davis BP, Palmiter RD, Brinster RL. 1986. Tissue-specific expression of pancreatic genes in transgenic mice. Ann NY Acad Sci 478: 131-146.
Madisen L, Groudine M. 1994. Identification of a locus control region in the immunoglobulin heavy-chain locus that deregulates c-myc expression in plasmacytoma and Burkitt's lymphoma cells. Genes Dev 8: 22122226.

Maglione JE, Moghanaki D, Young LJT, Manner CK, Ellies LG, Joseph SO, Nicholson B, Cardiff RD, MacLeod CL. 2001. Transgenic polyoma middle-T mice model premalignant mammary disease. Cancer Res 61: $8298-8305$.

Martin GS. 1970. Rous sarcoma virus: A function required for the maintenance of the transformed state. Nature 227: 1021-1023.

Muller WJ, Sinn E, Pattengale PK, Wallace R, Leder P. 1988. Single-step induction of mammary adenocarcinoma in transgenic mice bearing the activated c-neu oncogene. Cell 54: 105-115.

Nusse R, Varmus HE. 1982. Many tumors induced by the mouse mammary tumor virus contain a provirus integrated in the same region of the host genome. Cell 31: 99-109.

Nusse R, van Ooyen A, Cox D, Fung YK, Varmus H. 1984. Mode of proviral activation of a putative mammary oncogene (int-1) on mouse chromosome 15. Nature 307: 131-136.

Ornitz DM, Palmiter RD, Hammer RE, Brinster RL, Swift GH, MacDonald RJ. 1985. Specific expression of an elastase-human growth hormone fusion gene in pancreatic acinar cells of transgenic mice. Nature 313: 600602.

Ornitz DM, Hammer RE, Messing A, Palmiter RD, Brinster RL. 1987. Pancreatic neoplasia induced by SV40 T-antigen expression in acinar cells of transgenic mice. Science 238: 188-193.

Palmiter RD, Brinster RL. 1985. Transgenic mice. Cell 41: 343-345.

Palmiter RD, Brinster RL, Hammer RE, Trumbauer ME, Rosenfeld MG, Birnberg NC, Evans RM. 1982. Dramatic growth of mice that develop from eggs microinjected with metallothionein-growth hormone fusion genes. Nature 300: 611-615.

Palmiter RD, Chen HY, Messing A, Brinster RL. 1985. SV40 enhancer and large- $\mathrm{T}$ antigen are instrumental in development of choroid plexus tumours in transgenic mice. Nature 316: 457-460.

Polack A, Feederle R, Klobeck G, Hortnagel K. 1993. Regulatory elements in the immunoglobulin kappa locus induce c-myc activation and the promoter shift in Burkitt's lymphoma cells. EMBO J 12: 39133920.

Quaife CJ, Pinkert CA, Ornitz DM, Palmiter RD, Brinster RL. 1987. Pancreatic neoplasia induced by ras expression in acinar cells of transgenic mice. Cell 48: 1023-1034.

Ringold GM, Yamamoto KR, Tomkins GM, Michael Bishop J, Varmus HE. 1975. Dexamethasone-mediated induction of mouse mammary tumor virus RNA: A system for studying glucocorticoid action. Cell 6: 299305.

Robinson GW, McKnight RA, Smith GH, Hennighausen L. 1995. Mammary epithelial cells undergo secretory differentiation in cycling virgins but require pregnancy for the establishment of terminal differentiation. Development 121: 2079-2090.

Ruther U, Komitowski D, Schubert FR, Wagner EF. 1989. c-fos expression induces bone tumors in transgenic mice. Oncogene 4: 861-865.

Schedl A, Montoliu L, Kelsey G, Schutz G. 1993. A yeast artificial chromosome covering the tyrosinase gene confers copy number-dependent expression in transgenic mice. Nature 362: 258-261.

Schmitt CA, McCurrach ME, de Stanchina E, Wallace-Brodeur RR, Lowe SW. 1999. INK4a/ARF mutations accelerate lymphomagenesis and promote chemoresistance by disabling p53. Genes Dev 13: 2670-2677.

Schoenenberger CA, Andres AC, Groner B, van der Valk M, LeMeur M, Gerlinger P. 1988. Targeted c-myc gene expression in mammary glands of transgenic mice induces mammary tumours with constitutive milk protein gene transcription. Embo J 7: 169-175.

Sinn E, Muller W, Pattengale P, Tepler I, Wallace R, Leder P. 1987. Coexpression of MMTV/v-Ha-ras and MMTV/c-myc genes in transgenic mice: Synergistic action of oncogenes in vivo. Cell 49: 465-475.

Slamon DJ, Clark GM, Wong SG, Levin WJ, Ullrich A, McGuire WL. 1987. Human breast cancer: Correlation of relapse and survival with amplification of the HER-2/neu oncogene. Science 235: 177-182.

Sleigh MJ, Topp WC, Hanich R, Sambrook JF. 1978. Mutants of SV40 with an altered small $t$ protein are reduced in their ability to transform cells. Cell 14: 79-88.

Sonnenberg A, van Balen P, Hilgers J, Schuuring E, Nusse R. 1987. Oncogene expression during progression of mouse mammary tumor cells; activity 
of a proviral enhancer and the resulting expression of int- 2 is influenced by the state of differentiation. EMBO J 6: 121-125.

Sparwasser T, Gong S, Li JYH, Eberl G. 2004. General method for the modification of different BAC types and the rapid generation of BAC transgenic mice. Genesis 38: 39-50.

Stehelin D, Varmus HE, Bishop JM, Vogt PK. 1976. DNA related to the transforming gene(s) of avian sarcoma viruses is present in normal avian DNA. Nature 260: 170-173.

Stewart TA, Pattengale PK, Leder P. 1984. Spontaneous mammary adenocarcinomas in transgenic mice that carry and express MTV/myc fusion genes. Cell 38: 627-637.

Storb U, O’Brien RL, McMullen MD, Gollahon KA, Brinster RL. 1984. High expression of cloned immunoglobulin $\kappa$ gene in transgenic mice is restricted to B lymphocytes. Nature 310: 238-241.

Sweet BH, Hilleman MR. 1960. The vacuolating virus, S.V. 40. Proc Soc Exp Biol Med 105: 420-427.

Swift GH, Hammer RE, MacDonald RJ, Brinster RL. 1984. Tissue-specific expression of the rat pancreatic elastase I gene in transgenic mice. Cell 38: 639-646.

Taub R, Kirsch I, Morton C, Lenoir G, Swan D, Tronick S, Aaronson S, Leder P. 1982. Translocation of the c-myc gene into the immunoglobulin heavy chain locus in human Burkitt lymphoma and murine plasmacytoma cells. Proc Natl Acad Sci 79: 7837-7841.

Tegtmeyer P, Schwartz M, Collins JK, Rundell K. 1975. Regulation of tumor antigen synthesis by simain virus 40 gene A. J Virol 16: 168-178.

Tehranian A, Morris DW, Min BH, Bird DJ, Cardiff RD, Barry PA. 1996. Neoplastic transformation of prostatic and urogenital epithelium by the polyoma virus middle T gene. Am J Pathol 149: 1177-1191.

Tsukamoto AS, Grosschedl R, Guzman RC, Parslow T, Varmus HE. 1988. Expression of the int-1 gene in transgenic mice is associated with mammary gland hyperplasia and adenocarcinomas in male and female mice. Cell 55: 619-625.

Tuveson DA, Zhu L, Gopinathan A, Willis NA, Kachatrian L, Grochow R, Pin CL, Mitin NY, Taparowsky EJ, Gimotty PA, et al. 2006. Mist1Kras ${ }^{G 12 D}$ knock-in mice develop mixed differentiation metastatic exocrine pancreatic carcinoma and hepatocellular carcinoma. Cancer Res 66: $242-247$.
Ursini-Siegel J, Schade B, Cardiff RD, Muller WJ. 2007. Insights from transgenic mouse models of ERBB2-induced breast cancer. Nat Rev Cancer 7: 389-397.

van Lohuizen M, Verbeek S, Scheijen B, Wientjens E, van der Gulden $\mathrm{H}$, Berns A. 1991. Identification of cooperating oncogenes in $\mathrm{E} \mu-m y c$ transgenic mice by provirus tagging. Cell 65: 737-752.

Wagner EF, Stewart TA, Mintz B. 1981. The human beta-globin gene and a functional viral thymidine kinase gene in developing mice. Proc Natl Acad Sci 78: 5016-5020.

Wagner KU, Wall RJ, St-Onge L, Gruss P, Wynshaw-Boris A, Garrett L, Li M, Furth PA, Hennighausen L. 1997. Cre-mediated gene deletion in the mammary gland. Nucleic Acids Res 25: 4323-4330.

Wagner K-U, Ward T, Davis B, Wiseman R, Hennighausen L. 2001. Spatial and temporal expression of the Cre gene under the control of the MMTVLTR in different lines of transgenic mice. Transgenic Res 10: 545-553.

Walker MD, Edlund T, Boulet AM, Rutter WJ. 1983. Cell-specific expression controlled by the $5^{\prime}$-flanking region of insulin and chymotrypsin genes. Nature 306: 557-561.

Wiman KG, Clarkson B, Hayday AC, Saito H, Tonegawa S, Hayward WS. 1984. Activation of a translocated c-myc gene: Role of structural alterations in the upstream region. Proc Natl Acad Sci 81: 6798-6802.

Yamamoto KR, Chandler VL, Ross SR, Ucker DS, Ring JC, Feinstein SC. 1981. Integration and activity of mammary tumor virus genes: Regulation by hormone receptors and chromosomal position. Cold Spring Harb Symp Quant Biol 45 Pt 2: 687-697.

Yamamoto KR, Payvar F, Firestone GL, Maler BA, Wrange O, CarlstedtDuke J, Gustafsson JA, Chandler VL. 1983. Biological activity of cloned mammary tumor virus DNA fragments that bind purified glucocorticoid receptor protein in vitro. Cold Spring Harb Symp Quant Biol $47 \mathrm{Pt}$ 2: 977-984.

Yang XW, Model P, Heintz N. 1997. Homologous recombination based modification in Esherichia coli and germline transmission in transgenic mice of a bacterial artificial chromsome. Nat Biotech 15: 859-865.

Zuber J, Shi J, Wang E, Rappaport AR, Herrmann H, Sison EA, Magoon D, Qi J, Blatt K, Wunderlich M, et al. 2011. RNAi screen identifies Brd4 as a therapeutic target in acute myeloid leukaemia. Nature 478: $524-528$. 


\section{Transgenic Mouse Models--A Seminal Breakthrough in Oncogene Research}

Harvey W. Smith and William J. Muller

Cold Spring Harb Protoc; doi: 10.1101/pdb.top069765

\begin{tabular}{rc}
\hline $\begin{array}{c}\text { Email Alerting } \\
\text { Service }\end{array}$ & Receive free email alerts when new articles cite this article - click here. \\
\hline $\begin{array}{c}\text { Subject } \\
\text { Categories }\end{array}$ & Browse articles on similar topics from Cold Spring Harbor Protocols. \\
& BACs (33 articles) \\
& DNA Delivery/Gene Transfer, general (341 articles) \\
& Transgenic Mice (139 articles) \\
& Transgenic Technology, general (187 articles) \\
& Viral Methods (113 articles) \\
\hline
\end{tabular}

